\title{
LETTERS
}

\section{A Call to Conscience: A European Mirror of Truth Marion Wollersheim}

W hen we hear in the Netherlands of the justice system in the USA, it begins to clearly and rightfully evoke a deep-seated fear. For in many ways, it has begun to sound like the old Germany, which was never able to stop the rise of the Nazis in tormenting and attempting to eradicate their so-called undesirables; much like the United States appears to have never been able to fully let go of the concept of slavery. If you do not believe me, look at the States of Alabama and Arizona, where they flaunt the image of chained human beings whom a court has declared undesirable or enemies of the state, herding them under muzzles of guns along their roadways.

Next, look to Texas, where they all too proudly like to show visitors their museum that demonstrates the process used to kill that state's prisoners. I am talking about Huntsville, Texas's largest prisoner detention centre. How truly morbid it seems, to find a civilized nation in this day and age, callously boasting of a newer and alternative version of Dachau, with the only difference being the execution of human beings one at a time. I can only stare in horror at the mind-set behind such a phenomenon.

Aside from the prisons and guards there, we also hear that the Texas Correctional Industries aspires to be the third largest corporation in the United States. Not only do they have their license plate, license plate sticker, engraving, and records and conversion plants, but also, box, mattress, furniture, shoe, soap, canning, and brush factories, all making big money utilizing prisoner labour with no wages. Are they too, some new alternative to something else, such as a pre-civil war cotton field? And do all those industries give prisoners any skills that will allow them to move away from a life of crime, or do they just perpetuate another future pool of cheap labour to help Texas realize its corporate dream? In the end, hopefully someone will realize that when that misleading corporate dream has been achieved, it will have been achieved at the human cost of another future taxpayer being victimized, because the prisoner who will eventually be released has for years and often decades, been shown nothing meaningful; other than the fact that $s /$ he was hopelessly trapped in the cycle of a social dilemma from which only 
a few knowing people could have or really wanted to release him or her. Look at how little prisoners are allowed to financially prepare themselves for their release, and you will soon realize this claim substantiates itself.

We were also thinking long and hard, as to why the United States was not allowing China to sell things in America that political prisoners in China had made. In looking more closely at that fine line between what the United States considers acceptable for its own prisoners, and that which intrudes upon a Chinese prisoner's rights, from a realistic perspective that distinction eludes us. But also, we wonder if the United States could meet those same standards and purported objectives of such laws, if they were applied in an unbiased and factual manner against its own prisons and prisoners? When we hear and read, that in Texas, homosexuals and burglars can be shot and killed without the judges handling those cases as killings, we, as thinking and compassionate human beings, become even more fearful of your nation touting itself as a world leader. For what is the message being sent to other nations who have succeeded in moving forward with time, truly showing and respecting equality among their people, when the United States moves toward accepting public acts of hostility on the fringes of decadent barbarism for the sake of extolling discriminative selection? It is not a good message at all my dear American neighbours!

Here in the Netherlands, we often perceive the United States' justice system as just being the same one slavery was; only slightly evolved from a time when blacks were allowed to be killed, raped, and have their children sold. The only difference being, that today the system includes Hispanics, Native Americans, poor whites, and all those who lack the intellectual or mental ability to end up trapped in that broad scope of revenge hidden in the name of justice. It is a startling and cold truth to face.

How ironic it was to have watched the United States seek the freedom of former prisoner Nelson Mandela, when that same United States created the situation that made Amnesty International have to begin collecting information regarding racial discrimination in the application of its death penalty. Although the freedom and eventual election of Nelson Mandela was a beautiful thing to see, I could not believe my eyes when President Clinton and Hillary were in South Africa celebrating Mandela's election, when I knew fully well that President Clinton 
had previously approved the execution of a black man, who had undergone a lobotomy and had the mentality of a five year old child.

Here in the Netherlands, people who commit crimes are punished also. But here, we think that it is quite enough to send them to prison, to reflect upon whether or not money is worth the price of their freedom. As you may have guessed from the preceding sentence, most of the crimes here, are to basically get money. But, never does it occur with the frequency that it does in the United States; nor do people become so aggressive from the feeling of having been made worthless, that they hurt or kill others. Here, they are handled with the basic respect every creature needs to live a normal life. For some, this may seem like a strange concept, but it has worked extremely well in making the Netherlands one of the least violent nations in the world.

It is surely another point to discuss, regarding exactly how severe prisoners need to be punished or treated, in learning that they have done something wrong. Here in the Netherlands, we wonder how some people could end up receiving sentences as long as 133 years. In saying this, it is meant that someone who perhaps needed such a lengthy sentence, may have instead needed the services of a doctor to help him function in society as he should have. That someone could perceive giving another such an unbelievably long sentence, perhaps is in need of a doctor too! In truth, it denotes that there is something basically wrong, and it is being overlooked in the hysteria of seeking revenge, i.e., the causes of crime.

All crimes have some reason(s) for their occurrence, but if no one attempts to address those reasons, there can never be any solutions. The abuse of prisoners does nothing to address reasons or causes, for it only works to diminish their self-respect and create a deep seated hostility, from which little or no respect for their tax-paying tormentors can ever come. This is one fundamental flaw in your justice system, that desperately needs to be realized and addressed.

For the United States will otherwise embark upon a journey from which it may never be able to return to a progressive path. It has already nearly surpassed the staggering numbers the former Soviet Union had in imprisoning its citizens before its demise.

Although some answers may never be easy to initially accept, perhaps it is time to look to the progressive nations that have justice systems that work; for the fruits of today's American justice system are 
not the legacy you will want to leave children of the next millennium. For in time, that legacy will only eventually begin to look more like those of the old Germany and the no longer existing empire of the Soviet Union in the eyes of all those yet unborn children and the rest of the world.

Is that what people truly want for America? 